\title{
Usaha Peningkatan Kesehatan Masyarakat menghadapi Masa New Normal melalui Ceramah Edukatif Covid 19 dan Praktek Pembuatan Hand Sanitizer
}

\author{
Warsidah $^{1}$, Mega Sari Juane Sofiana ${ }^{1}$, Apriansyah ${ }^{1 *}$, Asri Mulya Azhari ${ }^{2}$ \\ ${ }^{1}$ Jurusan Ilmu Kelautan, Fakultas FMIPA, Universitas Tanjungpura \\ ${ }^{2}$ Jurusan Agroteknologi, Fakultas Pertanian, Universitas Tanjungpura \\ *Correspondent Author: apriansyah@fmipa.untan.ac.id
}

\begin{abstract}
ABSTRAK
Pandemi Covid-19 secara global telah berdampak pada semua sektor kehidupan. Memakai masker, mencuci tangan dan menjaga jarak dikenal dengan slogan 3M telah menjadi protokol utama kesehatan dalam usaha memutus mata rantai penyebaran Covid-19 di Indonesia. Mencuci tangan dilakukan dengan menggunakan sabun dan membilas di air mengalir, untuk tujuan mematikan kuman di tangan sebelum dan setelah beraktivitas. Penggunaan hand sanitizer adalah alternatif lain mensterilkan tangan yang lebih praktis untuk tujuan yang sama yaitu mematikan kuman. Kegiatan Pengabdian Kepada Masyarakat (PKM) ditujukan untuk mengedukasi warga masyarakat Kuala II dalam memahami tentang penyakit Covid-19 dari gejala, pengobatan sampai pencegahan atau pemutusan mata rantai penyebarannya. Selain itu, dilakukan praktek pembuatan hand sanitizer berbahan tambahan gel aloe vera sebagai komoditas lokal yang ada di Kuala II. Metode kegiatan pelaksanaan PKM antara lain adalah dengan ceramah edukatif tentang Covid-19, demonstrasi dan praktek pembuatan handsanitizer pada warga masyarakat Kuala II. Hasil kegiatan menunjukkan respon dan antusiasme warga masyarakat sangat tinggi. Sebanyak 13 peserta yang hadir sebagai perwakilan masing-masing RT di desa tersebut menunjukkan peningkatan pemahaman dan pengetahuan tentang Covid-19 terkait dengan gejala dan pengobatan serta pencegahannya, sekaligus juga sudah memiliki keterampilan membuat hand sanitizer dengan cara yang praktis dan peralatan sederhana.
\end{abstract}

Kata Kunci: Edukatif, Covid-19, Hand Sanitizer, New Normal

Received: July 8, 2021

Revised: August 10, 2021

Accepted: September 1, 2021

This is an open-acces article distributed under the terms of the Creative Commons Attribution-ShareAlike 4.0 International License.

\section{PENDAHULUAN}

Pandemi Covid-19 melanda dunia termasuk Indonesia, dan berdampak pada semua sektor kehidupan terutama perekonomian masyarakat. Menurut Yuliana (2020), Covid-19 merupakan bagian dari virus corona yang mengakibatkan penyakit dari yang bergejala ringan sampai parah seperti pilek, batuk, pneumonia dan MERS serta SARS, dengan ciri-ciri antara lain, penularan yang sangat cepat melalui percikan air liur/ludah/sekresi penderita, bergejala demam tinggi dengan suhu di atas $38^{\circ} \mathrm{C}$, batuk, rasa sesak pada saluran pernafasan. Virus corona jenis ini sangat rentan menginfeksi saluran pernafasan, begitu juga dengan orang tua usia lanjut dan orang yang memiliki penyakit bawaan atau penyakit utama yang serius seperti penyakit jantung, kanker, diabetes dan hipertensi.

Berbagai macam intervensi pemerintah dalam usaha memutus mata rantai penyebaran Covid19 sejak pertama dinyatakan pandemi Covid-19 pada bulan Maret 2020 sampai sekarang, antara lain pemberlakuan pembatasan jarak dengan tidak boleh adanya ditemukan kerumuman atau titik kumpul 


\section{Journal of Community Engagement in Health}

http://jceh.org

https://doi.org/10.30994/jceh.v4i2.250

ISSN: 2620-3758 (print); 2620-3766 (online)

Vol. 4 No 2. Sep 2021. Page. 355-362

massa di lokasi tertentu, pembatasan sosial berskala sedang sampai besar (PSBB) di tahun 2020 . Peningkatan pasien dan korban meninggal karena Covid awal sampai pertengahan tahun 2021, pemerintah kembali mengambil kebijakan dengan Pemberlakuan Pembatasan Kegiatan Masyarakat (PPKM) di tahun 2021 yang berdampak pada menurunnya aktivitas perekonomian masyarakat yang pada akhirnya akan menurunkan daya beli masyarakat. Kelesuan terjadi di berbagai sektor kehidupan. Sampai saat ini, meskipun sebagian besar masyarakat telah divaksinasi, tetapi Dinas Kesehatan Provinsi Kalimantan Barat masih dengan tegas merekomendasikan cara pencegahan infeksi virus yang efektif adalah antara lain dengan menerapkan jaga jarak (physical distancing), wajib bermasker saat berada di tempat umum (WHO, 2020) dan wajib mencuci tangan dengan air dan sabun ataupun dengan hand sanitizer yang memiliki kandungan alkohol sebesar 60\% (Holifah et al., 2020). Memakai masker, menjaga jarak dan mencuci tangan dikenal dengan slogan 3M sebagai protokol kesehatan utama dalam menangani penularan infeksi Covid-19 secara massif, meskipun telah dilakukan vaksinasi Covid 19 secara massal kepada seluruh masyarakat Indonesia.

Mencuci tangan dengan sabun dapat mematikan kuman mikroba seperti bakteri, jamur dan virus karena sabun merupakan surfaktan yang dapat menurunkan tegangan permukan mikroba, yang menyebabkan membran sel mikroba pecah, isi sel akan keluar kemudian pada akhirnya akan mengalami kerusakan sel sampai kematian (Cavalieri, 2005). Hand sanitizer merupakan salah satu antiseptik yang secara praktis digunakan untuk membunuh kuman, karena dapat dibawa ke mana-mana, disimpan dalam saku ataupun tas dan dapat digunakan setiap diperlukan untuk membersihkan tangan baik sebelum maupun setelah beraktivitas.

Menyikapi keadaan ini, maka kami dari tim pelaksana kegiatan Pengabdian kepada Masyarakat (PKM) melakukan koordinasi untuk melakukan kegiatan edukasi sekaligus pelatihan pembuatan hand sanitizer kepada masyarakat. Kegiatan ini bertujuan untuk menambah pengetahuan masyarakat terkait dengan penyakit Covid-19 termasuk cara penanganan, pencegahan dan pengobatannya, sekaligus meningkatkan keterampilan masyarakat dalam membuat hand sanitizer sebagai cairan antiseptik tangan yang lebih praktis digunakan dibandingkan dengan antiseptik menggunakan sabun. Hand sanitizer adalah bahan atau produk antiseptik yang berbentuk gel ataupun berbentuk cairan sebagai pencuci tangan praktis untuk dibawa dalam perjalanan, karena dapat dikemas dalam wadah botol dari ukuran kecil sampai besar, dalam jenis botol spray ataupun botol pencet (Asngad et al., 2018). Menurut Fatmawati (2020), hand sanitizer adalah produk antiseptik yang penggunaannya lebih efektif dibandingkan dengan cuci tangan menggunakan sabun karena kesulitan mendapatkan air bersih untuk membilas saat dalam perjalanan.

Pada awal diumumkannya status pandemi Covid-19 di beberapa negara termasuk Indonesia, hand sanitizer menjadi hilang di pasaran, sulit mendapatkan atau dapat diperoleh dengan harga yang sangat mahal, demikianpun dengan pelarut alkohol yang merupakan bahan baku utama dari hand sanitizer. Tentunya hal ini membuat kepanikan bagi masyarakat umum. Tetapi untuk masa sekarang, dalam menghadapi masa new normal telah banyak bermunculan hand sanitizer dengan variasi bahan baku dan kemasan yang praktis. Menurut Nikmah (2019), produk hand sanitizer yang banyak di pasaran mengandung bahan seperti alkohol dan antiseptik golongan lain seperti triklosan yang aktivitasnya juga dapat menghambat pertumbuhan bakteri.

Meskipun efek antimikroba dari hand sanitizer ini sangat kuat, bereaksi cepat dengan penggunaan yang lebih praktis, tetapi penggunaan yang secara terus menerus dalam waktu yang lama dapat mengakibatkan kulit tangan menjadi kering dan akhirnya menimbulkan rasa panas (terbakar), karena kandungan alkohol dan oksidator kuat seperti peroksida.

Untuk itu dalam kegiatan PKM bertopik edukasi Covid-19 dan praktek pembuatan hand sanitizer pada masyarakat di Desa Kuala II ini dengan tim pelaksana dari Jurusan Ilmu Kelautan, akan digunakan herbal gel aloe vera sebagai bahan tambahan dalam formula hand sanitizer untuk menambah kekentalan produk sehingga mudah dioleskan pada tangan, menjaga kelembutan dan kelembaban kulit tangan yang kemungkinan disebabkan oleh sifat iritatif dari kandungan alkohol dalam formula aslinya berdasarkan Word Health Organization (WHO) (2010). 


\section{BAHAN DAN METODE}

Kegiatan PKM dilaksanakan dengan mengikuti beberapa tahap, antara lain :

1. Tahap Persiapan, konsolidasi tim dan konfirmasi pelaksanaan kegiatan

Tim pelaksana kegiatan melakukan konsolidasi tim dan mempersiapkan segala peralatan dan bahan dan materi ceramah ilmiah/edukatif yang akan digunakan dan disampaikan dalam pelaksanaan kegiatan PKM. Persiapan alat dan bahan antara lain adalah botol spray dan botol pencet/tuang, gelas ukur, alkohol, hidrogen peroksida $\left(\mathrm{H}_{2} \mathrm{O}_{2}\right)$, gel aloe vera, wadah pencampuran larutan hand sanitizer, minyak cengkeh dan essense melon sebagai pewangi, serta air bersih. Konfirmasi lanjut kepada pemerintah desa setempat terkait daftar calon peserta yang akan diundang, rencana jadwal pelatihan dengan menyesuaikan kesempatan waktu bagi calon peserta pelatihan. Tahapan ini dilaksanakan secara daring.

2. Tahap pelaksanaan kegiatan pelatihan

Pelaksanaan kegiatan dilaksanakan pada hari Sabtu tanggal 7 November 2020 secara offline dengan menggunakan protokol kesehatan secara ketat dalam memutus mata rantai penyebaran Covid-19. Pelaksanaan kegiaitan dibagi dalam 3 sesi kegiatan yaitu: 1) Ceramah ilmiah/edukatif tentang penyakit Covid-19, terkait gejala, penanganan pengobatan dan pencegahan/pemutusan mata rantai penyebaran, yang disertai dengan diskusi antar peserta dan pemateri; 2) Praktek membuat hand sanitizer berbahan utama alkohol dengan penambahan gel aloe vera sebagai bahan pelembab dan penghalus kulit tangan yang kemungkinan mengalami iritasi karena kandungan alkoholnya. Peserta pelatihan diibuat dalam 3 kelompok untuk memudahkan koordinasi. Praktek membuat hand sanitizer didemonstrasikan lebih dahulu, kemudian selanjutnya setiap kelompok membuat sendiri produk hand sanitizer yang dibimbing dan diarahkan oleh tim pelaksana kegiatan untuk para peserta kegiatan; 3) Evaluasi dan monitoring yang dimaksudkan untuk mengetahui tanggapan peserta dalam menerapkan materi edukasi, mengukur kemampuan dan keterampilan peserta dalam membuat hand sanitizer, serta mengukur kemajuan dan usaha keberlanjutan dari kegiatan pelatihan yang telah dilakukan. Monitoring akhir kegiatan dilakukan 2 minggu setelah pelaksanaan kegiatan.

\section{HASIL}

Pelaksanaan kegiatan PKM usaha peningkatan kesehatan masyarakat menghadapi masa new normal melalui ceramah edukatif Covid-19 dan praktek pembuatan hand sanitizer pada masyarakat Kuala II di Kecamatan Sungai Raya Kabupaten Kubu Raya pada tanggal 7 November 2020 dihadiri oleh 13 orang peserta undangan dari 20 undangan yang dipersiapkan. Kegiatan pelatihan ini berlangsung secara offline dengan tetap menggunakan protokol kesehatan yang ketat, yaitu menggunakan masker, mencuci tangan dan jaga jarak dengan menghindari kerumunan yang banyak.

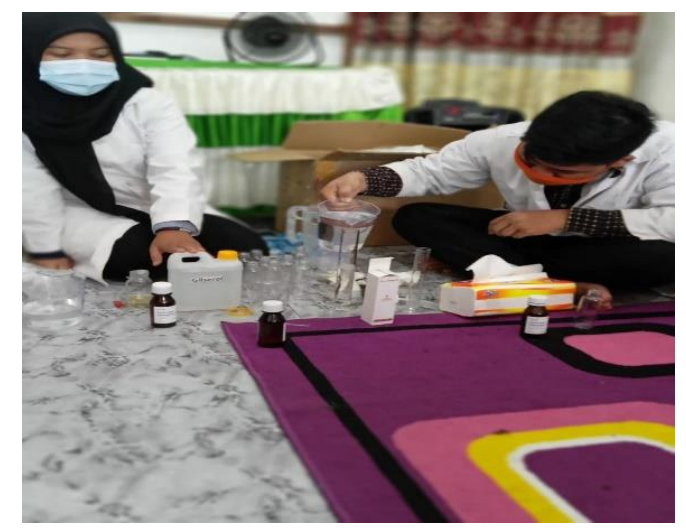

Gambar 1. Tim pelaksana menjelaskan dan mendemonstrasikan pembuatan hand sanitizer 


\section{Journal of Community Engagement in Health}

http://jceh.org

ISSN: 2620-3758 (print); 2620-3766 (online)

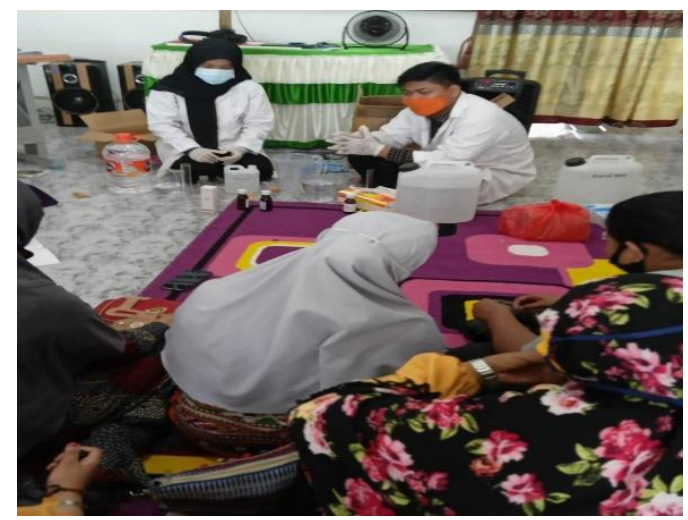

Gambar 2. Tim pelaksana dan peserta bersama-sama membuat hand sanitizer

Kegiatan berlangsung selama 5 jam, dimulai dengan penyampaian ucapan terima kasih dari ketua tim pelaksana kegiatan kepada pemerintah setempat dan para peserta yang sudah menyempatkan hadir. Selanjutnya penyampaian ceramah ilmiah (edukatif) terkait Covid-19 oleh tim pelakasana kegiatan, antara lain pemahaman tentang gejala, tindakan yang harus dilakukan saat merasakan gejala, kepatuhan dalam menjalankan isolasi mandiri jika pernah kontak dengan pasien yang terkonfirmasi positif, meningkatkan imunitas tubuh dengan mengonsumsi makanan yang sehat, menjaga kebersihan lingkungan keluarga dan masyarakat, istrahat yang cukup serta tidak melakukan kegiatan di luar rumah jika tidak terlalu penting, dan bagaimana usaha-usaha untuk mencegah penularan infeksi Covid 19 dalam menyambut masa New Normal setelah pandemi berakhir. Salah satu usaha yang ingin disosialisasikan ke masyarakat adalah pembuatan hand sanitizer.

Formula hand sanitizer yang direkomendasikan WHO (2010), mengandung bahan antara lain adalah $833,3 \mathrm{~mL}$ alkohol $96 \%$; 41,7 mL hidrogen peroksida $\left(\mathrm{H}_{2} \mathrm{O}_{2}\right) 3 \% ; 14,5 \mathrm{~mL}$ gliserol dan air bersih sampai volume $1.000 \mathrm{~mL}$ (1 Liter). Dalam pelaksanaan ini komposisi bahan tambahan dimodifikasi yaitu menambahkan gel aloe vera sebagai pengganti gliserol dan menambahkan berbagai minyak atsiri seperti minyak cengkeh, minyak sereh serta essense buah seperti essense melon, apel dan citrus untuk memberikan aroma wangi pada sediaan dan kulit tangan yang dioles.

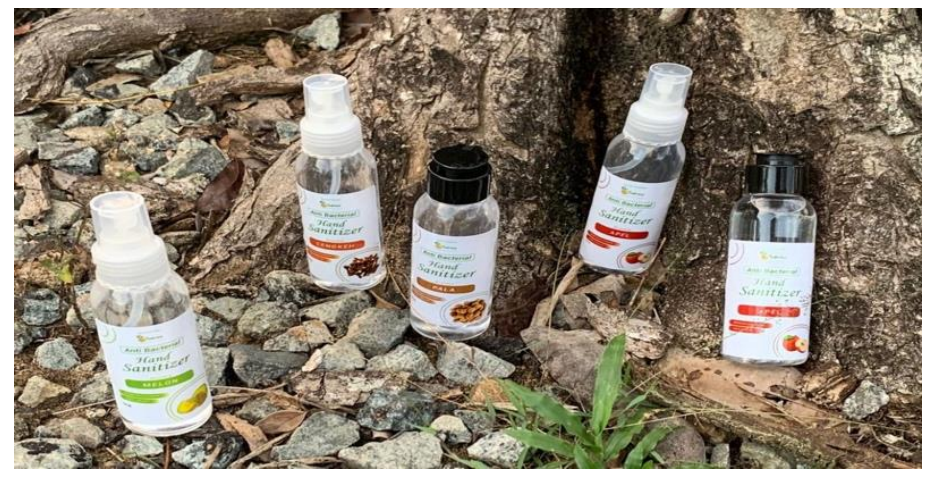

Gambar 3. Hand sanitizer yang telah diproduksi oleh peserta 


\section{Journal of Community Engagement in Health}

http://jceh.org

ISSN: 2620-3758 (print); 2620-3766 (online)

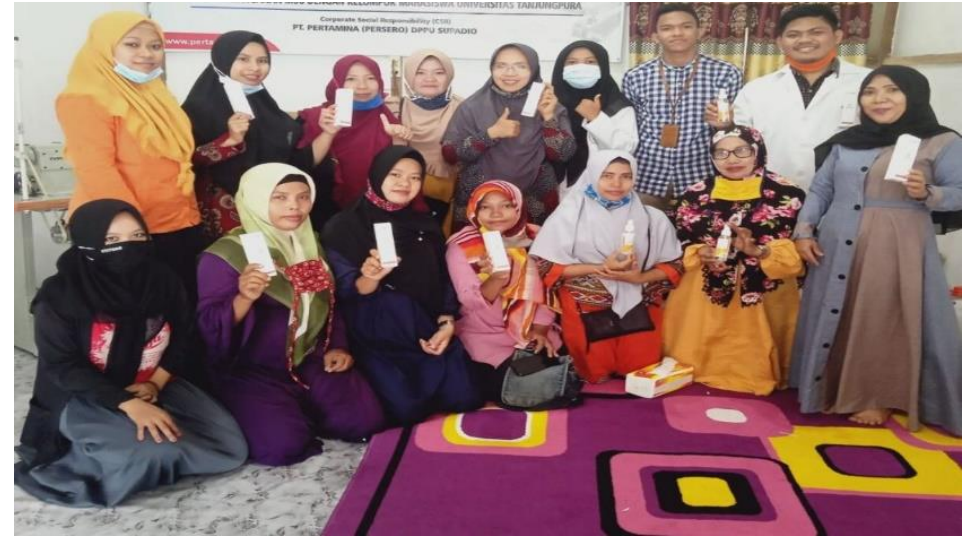

Gambar 4. Foto bersama setelah selesai kegiatan pelatihan

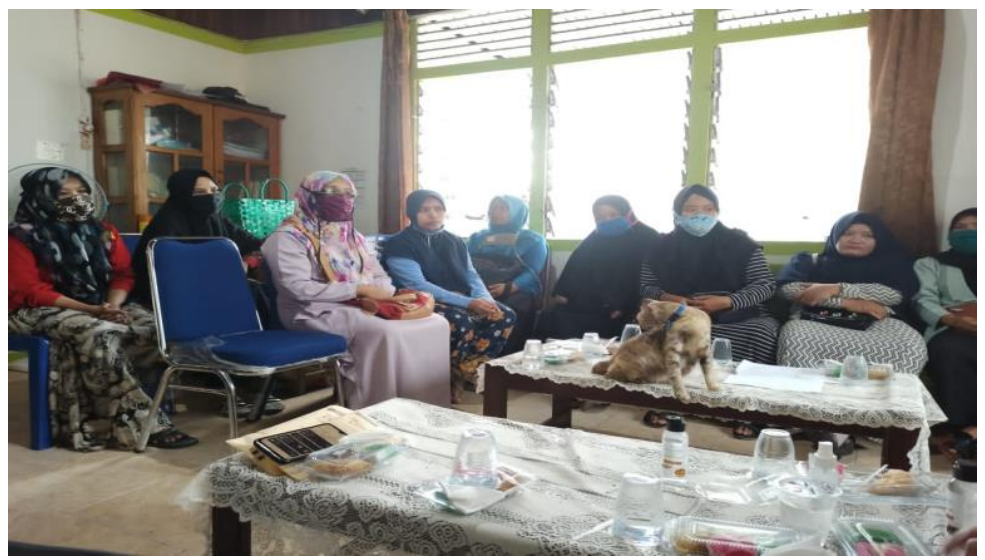

Gambar 5. Monitoring setelah 2 minggu pelaksanaan kegiatan

\section{PEMBAHASAN}

Berbagai usaha intervensi yang telah dilakukan oleh pemerintah dari pusat sampai pemerintah daerah dalam memutus mata rantai penularan infeksi Covid-19 antara lain dengan pembatasan jam aktivitas yang dapat menimbulkan keramaian, seperti mall, pasar, warung makan dan kafe-kafe, pembatasan sosial berskala besar, ternyata tidak efektif terhadap peningkatan jumlah pasien penderita Covid-19 dari bulan ke bulan. Slogan $3 \mathrm{M}$, memakai masker, mencuci tangan dan menjaga jarak bagi sebagian orang sering terabaikan. Hal ini mendorong tim pelaksana kegiatan untuk melakukan sosialisasi edukatif tentang Covid-19 kepada masyarakat Kalimantan Barat di antaranya dilakukan di Desa Kuala II Kecamatan Sungai Raya. Pelaksanaan kegiatan dilakukan setelah berkoordinasi dengan pemerintah dan warga setempat terkait rencana kegiatan yang akan melibatkan beberapa warga masyarakat, dan selanjutnya warga yang ikut kegiatan ini dapat menjadi penyampai informasi sekitar Covid-19 kepada masyarakat luas di sekitarnya. Ini adalah salah satu bentuk promosi kesehatan, yang dimaksudkan untuk menstimulasi masyarakat agar mau dan mampu meningkatkan kesehatan individu, apalagi dalam masa pandemi seperti sekarang (Notoatmodjo, 2010). Secara tidak langsung kita dituntut untuk dapat hidup berdampingan dengan Covid-19, keadaan yang diistilahkan New Normal, atau normal baru bahwa setiap individu sampai kelompok masyarakat luas dengan segala perilaku masingmasing selama ini dengan terpaksa akan mengalami perubahan pola kerja harian atau kebiasaan baik di rumah maupun di tempat kerja, yang berbeda dari dari pola sebelumnya (Irawati, 2020).

Edukasi tentang Covid-19 yang disampaikan oleh tim pelaksana adalah memuat materi antara lain bahwa Corona Virus Disease (Covid-19) yang disebabkan oleh virus Severe Acute Respiratory Syndrome Coronavirus-2 (SARSCoV-2) atau dengan kata lain Covid-19 merupakan penyakit kompleks yang melibatkan patologi imunologi, vaskular, dan metabolik akibat infeksi beta-coronavirus SARSCoV-2 (Utomo, 2020). Menurut Data Resmi dari Kementerian Kesehatan RI sampai tanggal 16 


\section{Journal of Community Engagement in Health}

http://jceh.org

https://doi.org/10.30994/jceh.v4i2.250

ISSN: 2620-3758 (print); 2620-3766 (online)

Vol. 4 No 2. Sep 2021. Page. 355-362

Februari Tahun 2021 telah melaporkan bahwa jumlah kasus positif sebanyak 1.233.959 orang, dan jumlah ini mengalami kenaikan yang signifikan dari bulan ke bulan. Kita perlu mengenal gejala-gejala terinfeksi virus Covid 19 antara lain adalah demam sampai $38^{\circ} \mathrm{C}$, batuk kering, kesulitan bernapas atau sesak napas, nyeri dada atau rasa tertekan pada dada, hilangnya kemampuan berbicara atau bergerak, sakit kepala, kerongkongan terasa kering (Yuliana, 2020). Pentingnya memahami gejala-gejala ini agar dapat segera mengambil langkah-langkah pengobatan dan pencegahan penularan bagi anggota keluarga lain yang tinggal serumah, mengobati diri sendiri sambil melakukan isolasi mandiri agar tidak memperluas penularan. Selain itu, ketika merasakan gejala seperti ini, kita harus menyampaikan kepada keluarga atau warga masyarakat yang kemungkinan dapat memberikan bantuan seperti mencarikan obat, membantu menyiapkan makanan jika harus melakukan isolasi mandiri. Keterbukaan tentang gejala ataupun sudah terkonfirmasi positif Covid-19 berdasarkan hasil pemeriksaan laboratorium sangat membantu pihak lain untuk melakukan antisipasi atau pencegahan dini, memudahkan penelusuran dengan kontak fisik sebelumnya dan tentunya akan mempercepat penanganan jika ada yang terinfeksi. Selain itu, materi yang disampaikan juga memuat tentang bagaimana pentingnya melakukan aktivitas rutin baik di rumah maupun di kantor dengan mengikuti protokol kesehatan dengan ketat, sebagai usaha untuk memutus mata rantai penyebaran virus Covid-19, dimulai dari individu, keluarga sampai kepada masyarakat luas, patuh pada slogan $3 \mathrm{M}$ dan beraktivitas di luar rumah di luar hari kerja kantor diusahakan untuk dibatasin, jika memang urusannya tidak begitu penting.

Slogan $3 \mathrm{M}$ yaitu memakai masker, menjaga jarak dan mencuci tangan adalah protokol kesehatan utama yang telah membudaya selama pandemi dan masa new normal. Mencuci tangan dengan sabun dan dibilas dengan air mengalir sangat direkomendasikan, tapi tidak semua rumah atau instansi dapat menyediakan sarana ini, sehingga untuk mengantisipasi terjaganya kebersihan tangan selama dalam perjalanan atau dalam jarak yang tidak terjangkau dengan sabun dan air bersih, maka dapat menggunakan hand sanitizer.

Hand sanitizer adalah cairan pembersih tangan yang digunakan sebagai alternatif untuk mencuci tangan selain menggunakan sabun dan air. Hand sanitizer merupakan produk kesehatan yang dapat mematikan mikroba tanpa menggunakan sabun dan bilasan air, sehingga lebih praktis dalam penggunaanya, dapat digunakan di mana saja dan kapan saja. Hand sanitizer ini digunakan pada tangan umumnya sebelum makan, setelah keluar dari toilet dan juga setelah membersihkan dan membuang sampah. Hand sanitizer umumnya mengandung alkohol, meskipun ada saja di antaranya yang menggunakan antiinfeksi lain seperti triclosan dan sejenisnya. Untuk penanganan Covid-19, WHO (2020) merekomendasikan hand sanitizer untuk memutus mata rantai penyebaran Covid-19 harus mengandung alkohol $96 \%$ sekurang-kurangnya dari $60 \%$ dalam satu formula, hidrogen peroksida sebagai oksidator kuat sehingga formulasi ini memiliki aksi ganda dalam membunuh kuman virus Covid-19. Selain itu penambahan gliserol ke dalam formula dimaksudkan untuk melembabkan kulit dan mengurangi iritasi akibat penggunaan alkohol dan hidrogen peroksida dalam formula tersebut.

Pada sesi berikutnya dari kegiatan ini adalah praktek membuat hand sanitizer pada masyarakat Desa Kuala 2 ini, dihadiri oleh 13 orang peserta dari yang diundang sebanyak 20 orang. Peserta sangat antusias mengikuti bimbingan dan arahan tim pelaksana kegiatan mulai dari penyiapan dan perkenalan bahan dan alat yang digunakan dalam kegiatan tersebut. Kegiatan ini diharapkan dapat meningkatkan pengetahuan dan tingkat kepedulian peserta terhadap pentingnya menjaga kebersihan tangan dalam mencegah infeksi virus yang membahayakan kesehatan. Dalam pembuatan hand sanitizer berdasarkan rekomendasi WHO ini, ada modifikasi penggantian gliserol dengan gel aloe vera yang dimaksudkan untuk memberikan kelembaban pada kulit tangan karena adanya alkohol dan hidrogen peroksida yang memiliki sifat iritasi kuat pada kulit yang dioles. Aloe vera merupakan salah satu komoditas lokal Desa Kuala II, sehingga mudah untuk mendapatkannya dan masyarakat di daerah ini sudah dapat melakukan ekstraksi gel dari lidah buaya sehingga memudahkan tim pelaksana dalam menyediakan bahan pengganti gliserol ini pada saat pelaksanaan kegiatan. Jumlah gel aloe vera yang ditambahkan ke dalam campuran larutan alkohol $96 \%$ sebanyak $833 \mathrm{~mL}$, hidrogen peroksida $3 \%$ sebanyak $41 \mathrm{~mL}$, adalah sebanyak $10 \%$ atau $100 \mathrm{~mL}$ dalam $1 \mathrm{~L}$ campuran larutan, kemudian volume dicukupkan dengan air bersih sampai $1 \mathrm{~L}$, kemudian diaduk sampai homogen. Selanjutnya adalah menambahkan pewangi ataupun minyak atsiri ke dalam larutan, dimaksudkan untuk menutup bau yang tidak enak dari peroksida dan alkohol. Minyak atsiri seperti minyak pala, cengkeh dan sereh wangi selain memberikan wangi 


\section{Journal of Community Engagement in Health}

http://jceh.org

https://doi.org/10.30994/jceh.v4i2.250

ISSN: 2620-3758 (print); 2620-3766 (online)

Vol. 4 No 2. Sep 2021. Page. 355-362

yang khas pada sediaan juga memiliki efek ganda sebagai antiseptik. Penambahan essense buah-buahan seperti melon, apel dan citrus disesuaikan dengan selera wangi masing-masing, demikian juga dalam pemilihan minyak atsiri.

Respon peserta pelatihan dalam kegiatan praktek membuat hand sanitizer ini terlihat sangat antusias apalagi dengan memanfaatkan komoditas lokalnya yaitu aloe vera. Selain itu, penggunaan yang praktis dari hand sanitizer ini baik dalam penggunaan sehari-hari di rumah atau di kantor dan dalam perjalanan ke mana saja, telah memotivasi masyarakat untuk dapat membuat produk ini secara mandiri, dan berharap bahwa produk yang dibuat mereka dapat dipasarkan secara lokal, mengingat bahwa produk handsanitizer ini memang sudah menjadi kebutuhan utama dalam menunjang kebersihan tangan, baik selama masa pandemic maupun setelah menghadapi masa new normal ke depannya.

Pada monitoring di minggu kedua 21 November 2020 yaitu sebagai usaha dari tim pelaksana untuk mengukur keberhasilan dari kegiatan yang telah dilaksanakan sebelumnya menunjukkan bahwa masyarakat sudah memiliki pemahaman yang lebih banyak terhadap Covid-19 dan lebih patuh pada protokol kesehatan dalam memutus mata rantai penyebaran Covid-19, sudah dapat memproduksi hand sanitizer untuk keperluan keluarga, anak-anak sekolah. Selain itu, masyarakat menginginkan adanya kelanjutan dari kegiatan ini yang dapat mengedukasi dan meningkatkan keterampilan masyarakat dengan memanfaatkan komoditas lokal di daerah Kuala II dalam meningkatkan pendapatan setelah pandemi Covid-19 berakhir.

\section{KESIMPULAN}

Dari hasil kegiatan PKM Usaha Peningkatan Kesehatan Masyarakat menghadapi Masa New Normal melalui Ceramah Edukatif Covid-19 dan Praktek Pembuatan Hand Sanitizer pada masyarakat Kuala II di Kecamatan Rasau Jaya Kabupaten Kubu Raya, dapat disimpulkan :

1. Masyarakat sudah memahami tentang gejala infeksi Covid-19, beserta faktor-faktor yang dapat menjadi pemicu infeksi virus tersebut, penanganan dan pencegahannya.

2. Masyarakat Kuala II melalui perwakilan peserta yang diundang dalam pelatihan menunjukkan kemampuan dan keterampilan dalam membuat hand sanitizer sebagai alternatif pembersih tangan.

\section{REFERENSI}

Asngad, A., Bagas, A.R, Nopitasari. (2018). Kualitas Gel Pembersih Tangan (Handsanitizer) dari Ekstrak Batang Pisang dengan Penambahan Alkohol, Triklosan dan Gliserin yang Berbeda Dosisnya. Jurnal Bioeksperimen, 4(2): 61-70.

Cavalieri, S.J., Rankin, I.D., Harbeck, R.J., Sautter, R.S., McCarter, Y.S., Sharp, S.E., Ortez, J.H., Spiegel, C.A. (2005). Manual of Antimicrobial Susceptibility Testing. USA: American Society for Microbiology.

Fatmawati, F. (2020). Edukasi Penggunaan Hand Sanitizer dan Pembagian Hand Sanitizer Disaat Pandemi Covid-19. JCES, 3(2): 432- 438.

Holifah, Ambari, Y., Ningsih, A.W., Sinaga, B., Nurrosyidah, I.H. (2020). Efektifitas Antiseptip Gel Hand Sanitizer Ekstrak Etanol Pelepah Pisang Kepok (Musa paradisiaca L.) Terhadap Bakteri Staphylococcus aureus dan Escherichia coli. Jurnal Ilmiah Medicamento, 6(2): 123-132.

Irawati, T. 2020. Menuju Adaptasi Kebiasaan Baru. Direktorat Promosi Kesehatan dan Pemberdayaan Masyarakat. Kementerian Kesehatan RI., diakses dari https://promkes.kemkes.go.id/menujuadaptasi-kebiasaan-ba

Nikmah, A. (2019). Uji Efektivitas Ekstrak Buah Pare (Momordica charantia) Sebagai Hand Sanitizer Alami Dalam Menurunkan Jumlah Koloni Mikroba Pada Tangan. Skripsi: Program Studi Pendidikan Biologi Fakultas Keguruan Dan Ilmu Pendidikan Universitas Muhammadiyah Malang.

Notoatmodjo, S. (2010). Promosi Kesehatan Teori dan Aplikasi. Jakarta: Rineka Cipta

Utomo, A. (2020). Knowing When and How to Fight: COVID-19 Between Viral Clearance and Immune Tolerance. Journal of Biomedicine and Translational Research, 6(2) : 63-73. 


\section{Journal of Community Engagement in Health}

http://jceh.org

https://doi.org/10.30994/jceh.v4i2.250

ISSN: 2620-3758 (print); 2620-3766 (online)

Vol. 4 No 2. Sep 2021. Page. 355-362

World Health Organization. (2010). Guide to Local Production: WHO-Recommended Handrub

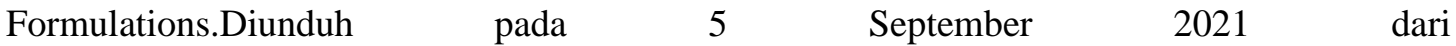
https://www.who.int/publications/i/item/WHO-IER-PSP-2010.5

World Health Organization. (2020). Mask Use in the Context of COVID-19. Diunduh pada 5 September 2021 dari https://apps.who.int/iris/bitstream/handle/10665/337199/WHO-2019nCov-IPC Masks-2020.5-eng.pdf?sequence $=1 \&$ isAllowed $=y$

Yuliana, 2020. Corona Virus Diseases (Covid-19): Sebuah Tinjauan Literatur. Wellness and Healthy Magazine, 2(1). 